\title{
Models, the Establishment, and the Real World: Why Do So Many Flood Problems Remain in the UK?
}

\author{
Colin Clark Chrs \\ Shute Lane, Bruton, Somerset, UK \\ Email: colin4chrs@hotmail.com
}

How to cite this paper: Chrs, C.C. (2017) Models, the Establishment, and the Real World: Why Do So Many Flood Problems Remain in the UK? Journal of Geoscience and Environment Protection, 5, 44-59. https://doi.org/10.4236/gep.2017.52004

Received: November 10, 2016 Accepted: February 7, 2017 Published: February 14, 2017

\begin{abstract}
In spite of the proliferation of research and Government Reports on floods in the UK, there are about 5 million properties located in flood prone areas. Many of the houses have been built during the past 50 years with little regard to the existing and future flood risk. Decision makers, who are part of the Establishment, rely on the outputs of models which are produced by so called "experts". But this information has been found to be flawed. However, the Establishment is largely unwilling to allow local knowledge when assessing flood risk, even though prevailing methodology suggests otherwise. This situation has grown worse since the formation of the Environment Agency in 1996. The public engagement with flood risk science and its application needs to proceed along a co-production of knowledge model. Three examples of the difficulties of making realistic assessments of fluvial flood risk are described. The problem of surface water flooding is also considered since it too has local causes which may not be accounted for in standard methodology. Finally, more open discussion and co-operation in identifying flood problems in the UK is called for.
\end{abstract}

\section{Keywords}

Models, Establishment, Historical Flood Data, Hypothesis Testing

\section{Introduction}

In prehistoric times the UK was populated by hilltop tribes. These were later displaced by the Saxon invaders who colonised the river valleys and gave rise to many towns and villages that exist today [1]. They were situated in a flood free position and the present day stone built churches, which may have replaced an earlier wooden place of worship, are well above the occasional flood level. After 
the Medieval period the growth of population, greater use of water power, and trade routes along bigger rivers, led to the building of houses on lower land. This increased the risk of damage from floodwater as a greater part of the floodplain became occupied. The period 1900-1945 saw very few serious and widespread floods, although the disastrous flood at Louth in 1920 should have prompted a careful look at other places which were at risk in the same way. Perhaps a greater acceptance of floods being considered an Act of God, lower living standards, and the effects of two World Wars that prevented improvement work on floods. In the $21^{\text {st }}$ century this situation has changed due to higher living standards and a more prosperous economy. Providing solutions to flooding problems has been a long and slow process. Since rivers existed before people arrived almost all the problems are man made: our prehistoric forefathers occupied flood free sites. The Saxon settlers chose sites high enough not to be washed away and low enough to be warm and avoid wind damage. Now, the seemingly intractable problem of flood alleviation is much more complicated. The following eight extracts introduce some of the issues. In this paper they are discussed in the context of the interaction of the public with the decision making Authorities. Three examples which exemplify the issues are then described.

Walter Kollmorgen: Settlement control beats flood control [2]

"A friend of mine remarked that before the flood he valued his land at \$300 per acre, but after the flood he valued it at $\$ 400$ per acre because fill of proper textured material had solved all drainage problems and removed all waste land. Flooded floodplains are in no way to be compared to an enemy, although our attack on flood problems suggests the lavish expenditures of money and resources thrown into a military campaign. Geographic engineering directed at settlement control can resolve many of the flood-loss problems".

Smith and Tobin: Human adjustment to the Flood Hazard. [3]

"As a result of inadequate planning policies and partial alleviation strategies, the responsible authorities have failed to contain the flood hazard. In essence, flood losses continue to rise because, in an increasingly crowded world, man has put a progressively higher premium on a floodplain location and the attendant risks of such development have been disregarded... Having failed to control floodplain settlement, the authorities have sought to control the rivers. Typically, this form of adjustment has relied on a structural approach with limited engineering work invariably undertaken after a flood event in response to pressure from floodplain dwellers... More recently, the authoritarian adjustment in many areas has included... flood forecasting and warning systems... Unfortunately, the mistakes associated with the structural adjustments have been repeated in that these schemes have been installed with comparatively little regard for social feasibility".

Environment Agency: Living with the risk [4]

"It's not possible to accurately forecast flooding in some areas such as parts of north Cornwall, where steep valleys mean that rivers can rise so rapidly after heavy rain that, with current technology, there's not enough time to issue warn- 
ings".

Paul Samuels: [5].

"Absolute protection from flooding cannot be achieved and the societal goal is for the management of flood risks at an "acceptable" level. Flood risk management therefore has the character of a "wicked problem" [6] in that flood risk is part of a broader environmental and social system, there are many potential solutions with no "true" or "false" answers and different stakeholders have differing (and potentially conflicting) views of the problem".

Interview with a Councillor at Pickering, Yorkshire UK [7].

"the hydrologists, the scientists are all going a very straight, linear route that is almost like purely theoretical. That would be ok if they were $100 \%$ right. Now they may be significantly correct, in terms of the proportions of what works, and what doesn't work, in terms of flood management. But I still feel even though I understand where they are coming from... there is a lot of historical evidence that they have just completely discounted in a very offhand way. And that there is a kind of myopia there that is again born of confidence, but confidence is moving into arrogance."

Interview with a second Councillor at Pickering [7].

“Don't trust the Environment Agency...if they get their experts on it, they will pay them a fortune, and they will come up with a massive system. The Environment Agency cannot be trusted."

National Flood Resilience Review [8].

"This is the first time that fluvial flood risk has been based on realistic rainfall scenarios and considered extreme events that are meteorologically plausible but lie outside existing observational records. Previous assessments have used peak river flows based on historical records. This means that this study is breaking new ground on how flood risk is assessed; however it is important to be clear about the scope of the study.... (Historic flood information) can have an impact on flood estimates but it is rarely used in the UK. Using data from historic sources, for example newspaper reports, photographs and sedimentary records, will supplement the observed record of flooding. Making greater use of this information would improve planning and management of extreme events in the future. Collating, storing and accessing this information in a way that enables it to be accessed by a wider range of users will be a key consideration.... It is estimated that without effective planning controls, pressure to build more homes could add up to $16 \%$ to the cost of optimal flood protection. In $2014 / 15$, $8 \%$ of new homes were built in flood zone 3, which has $1 \%$ annual chance of flooding from rivers or a $0.5 \%$ annual chance of flooding from the sea, if defences are not taken into account. Where the environment agency is aware of a planning decision notice, $97.8 \%$ of residential units in those planning decisions were in line with Environment Agency advice".

DEFRA Select Committee on Future flood prevention [9].

"Current flood risk management structures are fragmented, inefficient and ineffective... current arrangements do not encourage widespread use of catch- 
ment scale approaches. The Government's National Flood Resilience Review's limited solutions will not rectify fundamental structural problems: we propose a new governance model which the Government must consider as part of a root and branch review of how it manages England's flood risk.... current descriptions of a ' 1 in $x$ year' flood risk are confusing to the public. The Environment Agency and the Met Office must develop clearer methods by the end of this year, including maps showing all sources of flooding in one place". There are two areas of concern regarding these extracts which span a 60 year period. The first is knowledge the second, understanding

\subsection{Knowledge}

The effects of floods are not all bad [2]. Controlling where houses are built would help to avoid many floods. The belief of the Environment Agency [4] that it is not technically feasible to give a flood warning to people at Boscastle is completely wrong because they had already adopted a real time flood warning system for the upper Brue, which is in the same Region of the Agency [10]. A warning of 1 hour as could be provided by a flood warning system for Boscastle produced by the author [11] would have saved the destruction of about 40 cars and other property. The suggestion of Samuels [5] that floods are a "wicked problem" does not accord with Rittel \& Webber's [6] criteria of such problems in that they are clearly defined, the solution can be tested with the passage of time and the solution can be modified in the future in the light of new knowledge. Furthermore Conklin, 2006 [12] notes that these "wicked problems" do not have an alternative solution which is clearly not applicable to flooding problems. Wicked problems are those where the solution requires people to change their mindsets and behaviour. Good examples are climate change and nuclear weapons.

The historical knowledge that seems to be missing in the opinion of the Councillor at Pickering is the very information that is described in both the Flood Studies Report [13] and more explicitly in the Flood Estimation Handbook [14]. In the HMG [8] review of floods the value of historical flood information is stressed. Such information has been used in the design of flood schemes for over 50 years [15].

The National Flood Resilience Review shows that their knowledge is far from complete. The use of rainfall estimates [8] which fall outside the measured values was described for the river Brue by Clark [16] and for the Kenwyn at Truro [17]. More alarming is that nearly all of the houses built in 2014-2015 in flood prone areas were approved by the Environment Agency, showing a lack of knowledge to give better advice.

The Report from the DEFRA Select Committee shows a lack of knowledge of what exists to deal with problems of flooding. There is no alternative suggestion to describing the chances of a flood taking place, and while a new Body to oversee flooding was proposed, the additional knowledge that the Body should possess was not specified either implicitly or explicitly. 


\subsection{Understanding}

That floods are a problem caused by the ecological imbalance of Man and the environment was well understood by Kollmorgen [2]. Smith and Tobin [3] added their analysis of the situation with the problem of lack of space and by implication wrong choice of sites for building. Samuels [5] misses the point that some flood problems have become worse through the provision of poor road drainage and the significant raising of Highway surfaces: this point is described later in this paper.

The level of understanding of flood wave generation, and translation down the watercourse has eluded the Environment Agency [4]. The use of telemetered rainfall has been in use for decades [18], and it is significant that some staff of the Agency at Exeter in early 2004 did not know of the existence of the Tipping Bucket Raingauge at Lesnewth which is in the middle of the Valency catchment at Boscastle.

The Councillor at Pickering showed one important asset that scientists have, and that is the ability to question what is placed in front of them and to recall or even find out what has happened at Pickering in the past. A good example of this is the flood stone at the Town Mill in Gillingham, Dorset UK, which was taken away when the site was redeveloped in the late 1980's and shows the flood levels in $1768,1809,1882$, and 1917.

The two Government Reports published in 2016 show a lack of understanding by what is not stated as much as the content. This can best be improved by those who have had direct experience of floods over a long period of time. Unless hydrologists are better trained in the field, the level of uncertainty, which may be an excuse for the lack of more accurate forecasts, slows down future progress.

For Kollmorgen [2] the control of where houses are built is vital. Smith \& Tobin [3], suggested five ways of improvement: General education, Flood wardens, development controls on housing, a National Flood Policy made by Government, and further research into how people respond to floods. Samuels [5] concludes by stating: "Past research on flood risk management has brought real advances in knowledge and understanding which have been taken up into practice and have shaped changes in policy. However, looking to the future indicates that flood risks are set to increase driven by changes in climate, population, demographics and patterns of land use and settlement. Our management of floods and flood risks must respond to these pressures in a sustainable way which does not prejudice the ability of future generations to meet their own needs; again this points to adaptation as a key strategy".

For several sites in England such as the Upper Brue and Stour, and the Kenwyn, many of the worst floods have taken place before 1950. Thus the effect of climate change on future flooding will be difficult to prove, especially in view of the recent slow down of global temperature rise [19]. The call for more research when the solution to many flood problems is clear suggests that the study of floods has become a grow industry in itself as described by Whitmarsh [20].

Government based solutions focus on spending on flood mitigation $£ 2.3 \mathrm{bn}$ for 
the five year period 2016-2020 [8]. At the same time houses continue to be built in flood prone areas: as fast as money is spent on alleviating floods in one area, new problems are being produced. The suggestion of a new regulatory body to deal with floods seems perverse: successive Authorities such as the Water Boards constituted in the 1930's, the Water Authorities of the 1970's, the National Rivers Authority in 1990, and finally the Environment Agency which replaced the NRA in 1996, have failed to deal with the flooding problem in a comprehensive way.

\section{Interaction with the Public as an Impediment to Progress}

Perhaps it was the ground breaking paper by Callon [21] who highlighted the likely mistrust of the Public of technocrats and the growing divide between specialists and non-specialists. This is inevitable in a rapidly changing technological world, but it can lead to decisions that are later found to be wrong, which leads to further mistrust in the Authorities. He describes three models of interaction of the public and decision makers: first, the Public Education (PEM) model in which the authorities tell the public what is good for them and the latter accept the facts as given. Second, the Public Debate Model (PDM) wherein people are allowed to express an opinion. For example the planning process in the UK allows anyone to comment on the merits and defects of a new proposal. The third model is called the Co-production of knowledge Model (CKM). In this case there is more co-operation between the public and the decision makers which can lead to new information being incorporated into the decision making process. This allows a more open dialogue between the public and knowledge producers such as scientists whose knowledge may not be complete.

As an example of the CKM model in practice, Lane et al. [7] described the evolution of a solution to the flooding problem at Pickerng in Yorkshire UK. The situation started with great mistrust between local people and the Environment Agency which is contrary to their own guidelines [22]. At Pickering a traditional engineering solution to the floods did not meet economic criteria so the people were left without any significant help. A local flood research group was set up by inviting local people to become involved to try and improve the situation. The upper Pickering Beck had a low gradient which allowed the construction of low semi permeable wooden dams 2 - $3 \mathrm{~m}$ high across the valley storing big volumes of water. This scheme was adopted.

However, there is a wide variety of practice across the UK. This may be because of the attitudes of those concerned more than the decision making bodies themselves. The remainder of this paper will describe the nature of models, and the variability of response at three locations in southern England.

\section{The Nature of Hydrological Models}

A model can be described as a formal description of an opinion of how a system works. In the case of river floods in the UK this has been dominated by the Flood Studies Report [13], and the Flood Estimation Handbook [14]. It is 
worthwhile to note part of the disclaimer at the start of each of five volumes of the latter: "Neither the named authors not the Institute of Hydrology nor its parent bodies have approved any instruction that use of Flood Estimation Handbook procedures be made mandatory for particular application". Furthermore there are nearly six pages which describe the use of historical flood estimates, commenting that "Greater respect for historical flood data is recommended when they suggest that the preferred frequency curve may be too low". In addition a method of estimating bankfull discharge based on Wharton et al. [23] is described as a way of making an estimate of the 2-year flood, although many studies give a value of about 1.5 years for this parameter [24].

The problem with models is that their greatest asset is also their greatest weakness. They are easy to apply, the input data can be obtained from maps or from the FEH CDROM of catchment descriptors, and there is no need for time consuming fieldwork. Computer graphics make the results look even more convincing. Several different models can produce a range of answers. They are the consultant's paradise. There are assumptions regarding extreme value theory, multicollinearity, cumulative errors due to parameter specification, and the ever increasing mistake of simply believing the machine rather than the patient! Like any set of results or hypothesis, they are only scientific if they can be falsified [25]. The results of a flood frequency analysis should be tested with independent observations. If not then we are left with an unscientific theory. Buyer beware!

\section{The Upper Brue, Somerset UK}

The author's involvement with the river Brue goes back nearly 60 years. Two letters about the floods at Bruton published in the Western Gazette resulted in a letter from the Wessex Water Authority in 1978 asking for details of the studies made which focused on the flood history of the area. This resulted in a report [26]. What follows is a summary of events during the following 38 years.

1) May 1979 Bruton badly flooded.

2) September 1979. Meeting with WWA to discuss estimates of the peak flow of flood in May.

3) October 1979. WWA revised estimate of peak discharge.

4) Memorandum of Agreement between WWA and Rendle Palmer \& Tritton (RPT) to report on possible flood alleviation scheme.

5) February 1982. Reassessment of flood frequency of the Brue by the author based on a photograph of the aftermath of 1917 flood.

6) Progress report from RPT with estimate of Q100 35\% below author's revised flood frequency estimate. Senior Land Drainage Engineer, James Greenland endorses author's results.

7) $12^{\text {th }}$ July 1982 , major flood.

8) $13^{\text {th }}$ July report from RPT [27]. Main recommendations not affected by the flood. Comparing the historical results with their own, RPT stated: "However, in drawing a curve through the plotting positions of only 6 events in the historical sequence of more than 130 years total weighting is given to these big events 
whose plotting position is most in doubt".

9) Publication of new plotting equation based on probability and Monte Carlo analysis [28].

10) 1984 flood detention dam completed. Design spillway discharge $240 \mathrm{cu}-$ mecs.

11) Publication of rainfall frequency analysis of 44 sites in SW England [29] which suggested that FSR [13] rainfall estimates were too low.

12) 1995 Publication of new estimates of probable maximum precipitation [30] which showed that 24 hour PMP should be about $500 \mathrm{~mm}$ instead of 300 $\mathrm{mm}$.

13) May 1996 Report to Environment Agency regarding dam safety and design at Bruton. The storage volume had been overestimated by $26 \%$ and the PMF about 500 instead of 240 cumecs.

14) August 1996. Report by Babtie on Bruton dam [31] concluded: "No recommendations are made with respect to reassessing the PMP or PMF for the Bruton dam as a result of Clark's report... With respect to the reservoir storage volume it is recommended that a desk study is made using the largest scale contoured maps available to determine the depth-storage curve and check against the RPT and Clark data. A walked field survey would highlight any discrepancies. if considered necessary, a topographic survey of the reservoir basin could then be carried out".

15) Inclusion of the flood of 1768 in the authors flood frequency analysis [32]. Estimate of the 100-year flood increased to 90 cumecs.

16) 1996-2002. Protracted correspondence between the author and the Environment Agency.

17) 2003 Inspecting Engineer for Bruton dam, John Beaver, asks for a design standard assessment.

18) 2004 Environment Agency ask Black \& Veatch Consulting to report on author's paper: Bruton dam-a cause for concern [16].

19) November 2005 Report from Black and Veatch [33] concluded: that the PMF for Bruton dam site is 500 cumecs or higher, that the time to peak at the site is about 2 hours, that the percentage runoff could be up to $92 \%$, and a design rainfall of $245 \mathrm{~mm}$ in 4.25 hours should be used. The PMF would overtop the dam crest by $0.6 \mathrm{~m}$ and the dam spillway, which was armoured with petriflex blockwork with a density of $135 \mathrm{~km} \cdot \mathrm{m}^{-2}$ would be destroyed in about $30 \mathrm{~min}$ utes.

20) 2007: Author raises concerns that the crest should be protected with material stronger than Geotextile. Answers to questions not forthcoming over a period of several months.

21) 2007 the Bruton dam was raised by $2 \mathrm{~m}$ and the petrifex armouring was overlain by concrete tiles each weighing in excess of $100 \mathrm{~kg}$, with drainage holes that would tend to provide suction and therefore maintain their integrity during a major flood.

22) 2015. Remedial work on Bruton dam to install cellweb ${ }^{\text {tw }}$ protective mate- 
rial on the dam crest.

In conclusion the use of models was shown to be seriously flawed. Thankfully, with the supporting evidence of the historic floods, evidence from the Martinstown storm [34], and the soil survey data [16], a dam safe from being breached by extreme floods has been produced.

\section{The Valency at Boscastle in Cornwall}

The implications of the upper Brue study ought to have been propagated into other rivers at least in SW England where many of the most severe storms have taken place. Once again there was no measured flow data on the Valency so when the flood of August 2004 took place people at Hydraulic Research Wallingford estimated the flood frequency from local photographs and the collection of local archives made by residents Anne and Rodney Knight. The authors also used FEH methods.

The present author also made a study of the event starting in October 2004. The archives of several newspapers, and archive material of Anne and Rodney Knight were used as source material. A summary of events from January 2005:

1) Environment Agency announces findings of report into flooding at Boscastle.

2) January 2005, Author visits Agency office in Exeter and offers to show senior staff first results since published results seem to be in error. This offer was refused.

3) Visits HR Wallingford where the hydrological studies were carried out. Agreement over the 1 in 100 year event. Present author discloses that he used the pre-1960 bridge cross section for previous floods estimates: HR Wallingford used existing and bigger bridge section for all flood estimates.

4) May 2005 HR Wallingford report finished [35] but not made available for several months.

5) Long correspondence with Environment Agency regarding the inappropriate flood estimates.

6) June 2006, author publishes revised flood estimates [36] which prove that HRW estimates are too low at the more frequent end and far too high at the rare, +100 year flood. For example HRW estimated that the 2004 flood had a return period of about 400 years, while the flood producing rainfall had a rarity of several thousand years. The floods of 1882, 1894, 1903, 1911, and 1926 were not included in their report.

7) On site planning meeting in September 2006 to agree channel improvements to a design standard [35] of 70 years, as compared with a return period of 40 years [36].

8) The growth rate of floods in EX5160 [35] is far greater than any river in the whole of SW England.

9) The expected 1 in 1000 year flood in EX5160 is about 300 cumecs while the 1 in 5000 year flood is about 1000 cumecs. This has a rate of runoff of 50 cumecs per $\mathrm{km}^{2}$ which is 2.5 times greater than the Extreme catastrophic flood of Allard, 
Glasspoole \& Wolf [37].

10) If the flood estimates in EX5160 are correct then flooding in Boscastle should take place on average about once every 30 years. However, in the $20^{\text {th }}$ century there were floods in 1903, 1911, 1926, 1932, 1940's-exact date unknown, $1950,1958,1963$, and 1993. This gives an average time interval between floods of 12 years. For noticeable flooding to take place the author's estimate suggests a frequency of about 10 years. Table 1 shows the results of both studies.

It is clear that the Environment Agency has adopted the PEM of Callon [21]. In spite of serious and significant errors and omissions being pointed out, the report of May 2005 remained unchanged. As a result Boscastle has a flood alleviation scheme whose design standard will probably be exceeded in the next 30 years. What is even more alarming is that an alternative scheme to protect the area from fluvial flooding and costing about half of the cost of the channel improvements was not investigated thoroughly. Clearly the PKM was not considered by the Environment Agency.

The situation is made even worse since the Agency declined to use the author's flood warning flow model [11] which would have given at least one hour's warning for the 2004 flood.

\section{The Upper Stour at Bourton, Dorset}

The upper Stour drains an area of about $11 \mathrm{~km}^{2}$ at Bourton. There are four old earth dams upstream and one of these, Gasper Dam, was breached during the 1917 flood, causing much damage at Bourton and further downstream. No lives were lost. In 2004 an application to build about 30 houses on the former Bourton Mill site below the last of the four dams, led to the author being asked by the Local Council to investigate the flood hazard at the site [38]. The results showed that much of the site was vulnerable to serious flooding and in view of the poor condition of Gasper dam, the conclusion was that for the most part the site was unsafe for development. The Planning Application was refused at Committee stage and there was no appeal. The crucial reason for refusal was mainly the problem of flooding. One Councillor pressed the Environment Agency as to whether or not the site is in fact on a floodplain. The reply was affirmative.

In 2013 another application was made to build a lower number of houses with the addition of light industrial units, a Village Hall, and two low cost houses for

Table 1. Comparison of flood frequency estimates (cumecs).

\begin{tabular}{ccc}
\hline & This paper & EX5160 \\
\hline Q2 & 14 & 7 \\
Q25 & 44 & 26 \\
Q70 & 63 & 50 \\
Q100 & 74 & 63 \\
Q500 & 120 & 193 \\
PMF & 450 & Not given \\
\hline
\end{tabular}


local people. The developer employed engineering consultants [38] who used the models as described in the Flood Estimation Handbook [14]. This approach is for use when there are no riverflow data. However, the FEH does advocate the use of historical flood information. This can include photographs, eye witness accounts, newspaper reports and other archival material. There is a small but growing body of literature which suggests that when historic flood information is used, the estimated discharges are often higher than those predicted by using models. The disadvantage of using more direct hydrological analysis is that searching out and the interpretation of historic flood information can take considerable time, especially in the case of small rivers which tend not to have towns with good news coverage, or many people who have old photographs of floods that they and others have seen.

The response of both Planning Authority and the Environment Agency can be placed in the PEM. There was no opportunity to meet and discuss with the Developer's Consulting Engineer [39] and JBA, [40], who were asked to review the hydraulic modelling and dam break scenarios, but they failed to consider the reliability of the flood hydrology. The central problem was that the models had so much in common that they could not really represent independent assessments. Furthermore, there was no local or historic data used. While a report by Black \& Veatch for the 2004 application considered estimates of the peak flow of the July 1982 flood during which Bourton Mill was badly flooded, the 2011 consultants report ignored this and other events. The author's 2004 estimate of the flooding was extended to include 247 years' events, [41], which is the second longest record of a small catchment in the whole UK. In spite of this analysis, shown in Figure 1, the Environment Agency has allowed the development to proceed.

In mid 2016 after more questions were raised about the size of a downstream road bridge, it was admitted that the consultants had used the wrong sized section. Even a site visit by JBA, independent assessors in August 2011 [40] failed to check this important control of upstream water levels at Bourton Mill. Further questioning has shown that the use of bankfull discharge as a measure of the 1.1 2.0 year flood has been misunderstood by the Agency. Since bankfull discharge has been measured in the field [41] it is now certain that the Consultant's report is in serious error. This also means that the growth factor Q100/Q2 is much greater than their report suggests. It is well known that the model formulations of the FEH often overestimate the 2-year flood. This is because of the big scatter in the HOST [42] indices and standard percentage runoff, and the use of model I regression rather than model II which gives higher HOST percentage runoff rates at low values of observed percentage runoff, and vice versa.

\section{Surface Water or Pluvial Flooding}

The occurrence of flooding from sources other than rivers has been well known for decades [43]: the problem is growing [44]. While some lessons have been learnt from the summer 2007 floods [45] [46] there is hardly any mention of the effect of road levels being raised as much as $0.5 \mathrm{~m}$ above their historic level. This 


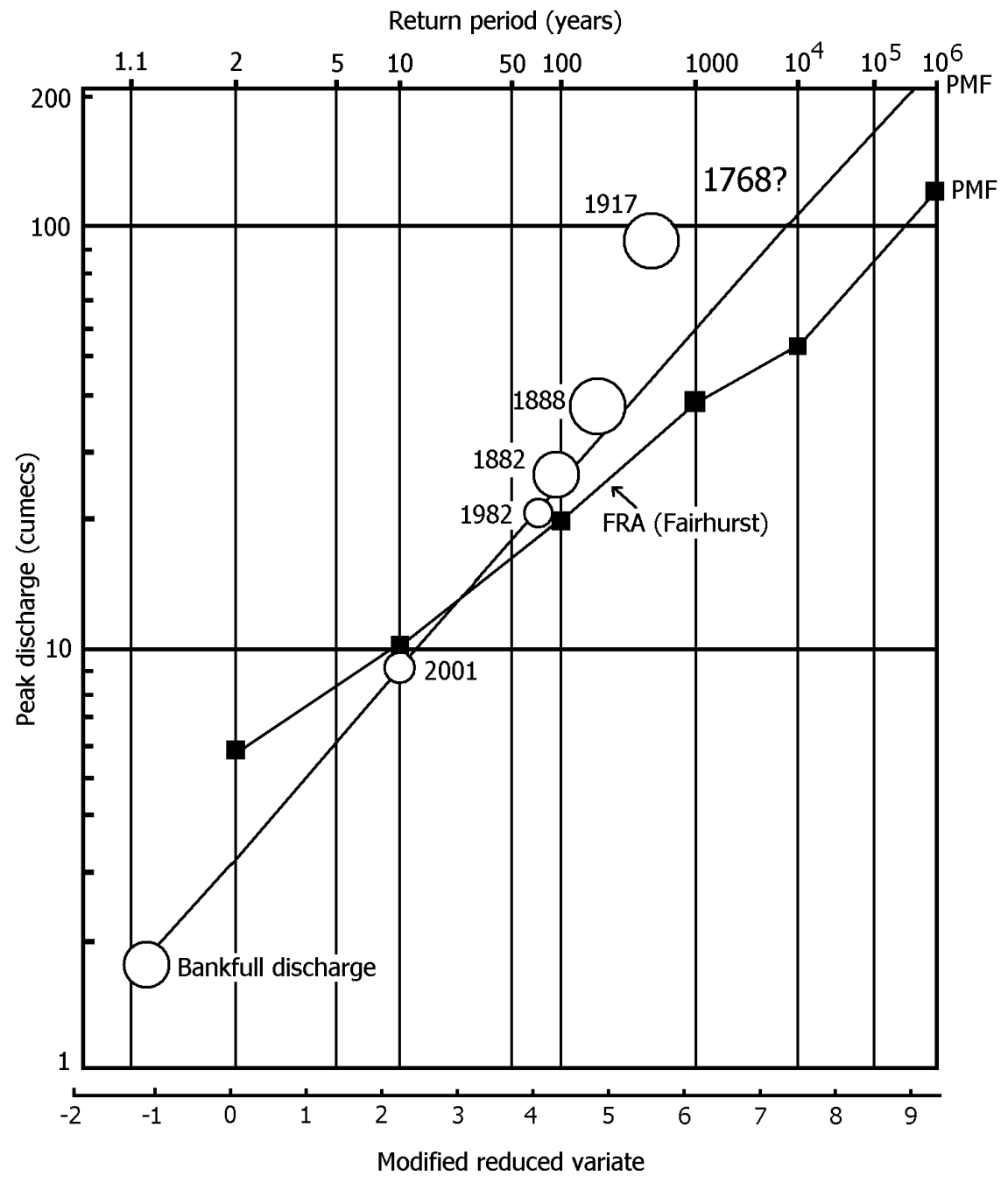

Figure 1. Two estimates of the flood frequency of the Upper Stour at Bourton, Dorset.

problem is widespread in rural areas, which again have been neglected in nearly all previous studies of pluvial flooding.

Two examples are worthy of note. The first is at Hadspen in East Somerset in May 1998. About $50 \mathrm{~mm}$ of rainfall took place in about an hour [47]. About 60 tonnes of soil were washed down the local valley, which was deposited onto the road surface. The road was already level with the threshold of nearby houses, and with the addition of about $0.3 \mathrm{~m}$ of soil caused considerable flooding to place. A report [48] showed that the road had been raised by up to $0.3 \mathrm{~m}$ in the past 90 years and that the road needed to be lowered. A similar situation exists at Combe in Oxfordshire [49]. Near one dwelling the District Council had cleaned out a 9 inch $(0.35 \mathrm{~m})$ pipe which took surface water to an open stream. Two weeks later another flood had taken place. The OS map for 1890 showed that part of the nearby road had been raised about $0.3 \mathrm{~m}$. Although an additional pipe has been installed the level of entry does not reduce the flood depth at the dwelling enough to avoid flooding in heavy rainfall. Over time with road resurfacing the level of many roads in rural areas has increased. This problem will 
become worse in the future unless steps are taken to bring the road level back to that which existed at least 70 years ago.

\section{Discussion}

There has been a tendency for the use of models as opposed to local data to assess flood frequency. In the case of the upper Brue it was the Wessex Water Authority that asked the author for information about historic floods. This led to more research and collaboration with WWA and also enabled the flood detention dam to be built [50]. By the time more recent research showed that the dam was in fact underdesigned and unsafe the organisation of the Water Industry had changed. Staff at Exeter and Bridgwater were unwilling to engage in any informal debate. The exception was in the production of the real time flood warning system. The lack of a PDM or the CKM are both apparent at both Boscastle and Bourton Mill.

In the future there will be even more pressure on building land, some of which may be at risk of serious flooding. Past experience of floods has not influenced National Policy anything like the extent that is needed in order to prevent widespread damage to property and death from drowning. While an allowance for climate change has been included in flood risk assessments, there is not enough knowledge about the natural variability of the system to make such allowances effective. When a flood scheme with a design standard of 1 in 100 is badly exceeded during a flood, will the confidence in other schemes be undermined? Models can also give a false sense of the accuracy of the results. Talking about the uncertainty of any result does not appear to change the final design. For example, at Bourton the consultants took the highest of several flood estimates, but at the same time ignored actual events for which evidence exists. Another problem with models is that they do not encourage the user to test the resulting hypotheses. For example, at Boscastle the results in EX5160 [35] could not match the observed frequency of flooding over a hundred year period. The FEH methods are based on riverflow records which are often much shorter than 50 years, while the rainfall estimates used in the FEH do not use data gathered before 1960. How this narrow data set can produce sensible estimates of rare flood events whose rarity is often in excess of 100 years is difficult to imagine.

Flood hydrology is essentially a field based science. Considerable fieldwork is needed to assess and produce solutions to surface water flooding that are caused by raised road levels. The answers to the questions that are badly needed will eventually be found in the field and not at the keyboard of the latest personal computer. The CKM needs to be fully embraced by all branches of the Establishment.

\section{References}

[1] Ekwall, E. (1960) A Concise Dictionary of the Place Names in England. Oxford Univ. Press, 456 p.

[2] Kollmorgen, W.M. (1953) Settlement Control Beats Flood Control. Economic Geography, 29, 208-215. https://doi.org/10.2307/142518 
[3] Smith, K. and Tobin, G.A. (1979) Human Adjustment to the Flood Hazard. Longman, New York, 130 p.

[4] Environment Agency (2005) Living with the Risk: The Flood in Boscastle and North Cornwall 16 August 2004. Exeter, 29 p.

[5] Samuels, P.G. (2013) Where Next in Flood Risk Management? A Personal View on Research Needs and Directions. 1-14, Proc. $2^{\text {nd }}$ European Conference on Flood Risk Management. FLOODrisk2012. 19-23 Dec. 2013.

[6] Rittel, H.W.J. and Webber, M.M. (1973) Dilemmas in a General Theory of Planning. Policy Sciences, 4, 155-169. https://doi.org/10.1007/BF01405730

[7] Lane, S.N., Odini, N., Landstrom, C., Whatmore, S.J., Ward, N. and Bradley, S. (2011) Doing Flood Risk Science Differently: An Experiment in Radical Scientific Method. Trans. Inst. Br. Geogr. NS, 36, 15-36. https://doi.org/10.1111/j.1475-5661.2010.00410.x

[8] HMG (2016) National Flood Resilience Review. London, 141 p.

[9] DEFRA (2016) Future Flood Prevention. Report of Select Committee. House of Commons. 53 p.

[10] Clark, C. (2004) A Non-Linear Unit Hydrograph Model for Real Time Flood Forecasting below a Dam. Internat. Water Power \& Dam Constr, 56, 20-26.

[11] Clark, C. (2006) A Real Time Flood Warning System for Boscastle, North Cornwall. Report to Environment Agency, Exeter, 18 p.

[12] Conklin, J. (2006) Dialogue Mapping: Building Shared Understanding of Wicked Problems. Chichester.

[13] NERC (1975) Flood Studies Report. 5 Volumes. Meteorological Office, London.

[14] IOH (1999) Flood Estimation Handbook. 5 Volumes. Wallingford.

[15] Harrison, A.J.M. (1961) The 1960 Exmouth Floods. The Surveyor and Municipal Engineer, 127-132.

[16] Clark, C. (1997) Flood Prediction and Control: Cause for Concern? Internat. Water Power \& Dam Constr, 49, 34-37.

[17] Clark, C. (2012) Spillway Design Flood and Flood Volume Estimated Using the New Guide to Flood Estimation. Flood Risk and Flood Management. In: Wong, T.S.W., Ed., Nova Science, New York, 219-255.

[18] Shaw, E. (1994) Hydrology in Practice. $3^{\text {rd }}$ Edition, Chapman \& Hall, London, 613 p.

[19] Koutsoyiannis, D., Makropoulos, C., Langousis, A. et al. (2009) Climate, Hydrology, Energy, Water: Recognizing Uncertainty and Seeking Sustainability. Hydrol. Earth Syst. Sci., 13, 247-257. https://doi.org/10.5194/hess-13-247-2009

[20] Whitmarsh, L. (2008) Are Flood Victims More Concerned about Climate Change than Other People? The Role of Direct Experience in Risk Perception and Behavioural Response. J. Risk Research, 11, 351-374. https://doi.org/10.1080/13669870701552235

[21] Callon, M. (1999) The Role of Lay People in the Production and Dissemination of Scientific Knowledge. Science Technology and Human Values, 4, 81-94.

[22] Environment Agency (2004) Building Trust with Communities: A Background Report for Environment Agency Staff.

[23] Wharton, G. Arnell, N.W., Gregory, K.J. and Gurnell, A.M. (1989) River Discharge Estimated from Channel Dimensions. J. Hydrol., 106, 365-376. https://doi.org/10.1016/0022-1694(89)90080-2

[24] Leopold, L.B., Wolman, M.G. and Miller, J.P. (1964) Fluvial Processes in Geomorphology. Freeman, San Francisco, 522 p. 
[25] Popper, K. (1959) The Logic of Scientific Discovery. Routledge, London, 513 p.

[26] Clark, C. (1979) Problems of Flooding at Bruton. Report to Wessex Water Authority, $26 \mathrm{p}$.

[27] Wessex Water Authority (1982) Bruton Flood Alleviation Study. Rendle Palmer and Tritton, London.

[28] Clark, C. (1983) Bruton Flood Alleviation Scheme: Benefit Assessment. Report to Wessex Water Authority, 21 p.

[29] Clark, C. (1991) A Four-Parameter Model for the Estimation of Rainfall Frequency in South West England. Meteorl. Mag., 120, 21-31.

[30] Clark, C. (1995) New Estimates of Probable Maximum Precipitation in South-West England. Meteorl. Appl., 2, 307-312. https://doi.org/10.1002/met.5060020403

[31] Environment Agency (1996) An Independent Review of Flood Alleviation Schemes Incorporating Flood Detention Dams Bruton Dam near Wincanton. Babtie, 32 p.

[32] Clark, C. (1999) The Great Flood of 1768 at Bruton, Somerset. Weather, 54 108-113. https://doi.org/10.1002/j.1477-8696.1999.tb06436.x

[33] Environment Agency (2006) Bruton Flood Storage Reservoir: Report on Hydraulic and Hydrological Studies. Black and Veatch.

[34] Clark, C. (2005) The Martinstown Storm 50 Years on. Weather, 60, 251-257. https://doi.org/10.1256/wea.58.05

[35] Environment Agency (2005) Flooding in Boscastle and North Cornwall, August 2004. Report EX5160. HR Wallingford 167 p.

[36] Clark, C. (2006) Planning for Floods: Will We Ever Learn? Internat. Water Power \& Dam Constr, 58, 20-27.

[37] Allard, W., Glasspoole, J. and Wolf, P.O. (1960) Floods in the British Isles. Pro. Inst. Civ. Engrs., 15, 119-144.

[38] Clark, C. (2004) Flood Frequency Analysis for the Upper Stour at Bourton, Dorset. Report Commissioned by Bourton Parish Council. 31 p.

[39] Fairhurst (2011) Bourton Mill. Flood Risk Assessments. Clublight Developments Ltd., $39 \mathrm{p}$.

[40] JBA (2011) Review Certificate. Bourton Mill FRA: Hydraulic Modelling of Fluvial and Dam Break Flooding. 9 p.

[41] Clark, C. (2015) A 247-Year Flood Record on the Upper Stour, Dorset UK. Weather, 70, 236-241. https://doi.org/10.1002/wea.2516

[42] Boorman, D.B., Hollis, J.M. and Lilly, A. (1995) Hydrology of Soil Types: A Hydrologically-Based Classification of the Soils of the United Kingdom. IOH Report $126,103 \mathrm{p}$.

[43] DOE (1995) The Occurrence and Significance of Erosion, Deposition and Flooding in Great Britain. HMSO, London, 177 p.

[44] JRF (2011) Pluvial (Rain Related) Flooding in Urban Areas: The Invisible Hazard. 95 $\mathrm{p}$.

[45] Coulthard, T.J. and Frostick, L.E. (2010) The Hull Floods of 2007: Implications for the Governance and Management of Urban Drainage Systems. J. Flood Risk Mangt, 3, 1-19. https://doi.org/10.1111/j.1753-318x.2010.01072.x

[46] Rozer, V., Muller, M., Bubeck, P., Kienzler, S., Thieken, A., Pech, I., Schroter, K., Bucholz, O. and Kreibich, H. (2016) Coping with Pluvial Floods by Private Households. Water, 8, 1-26. https://doi.org/10.3390/w8070304

[47] Clark, C. (2000) Storms, Floods and Soil Erosion: The Consequences of the Storm of 
13 May 1998 at Hadspen, Somerset. Weather, 55, 17-25. https://doi.org/10.1002/j.1477-8696.2000.tb04014.x

[48] Clark, C. (1999) Flooding at Lower Hadspen, May 1998. Report on Hydrology and Flood Alleviation. Commissioned by Lloyds Insurance. $13 \mathrm{p}$.

[49] Clark, C. (2011) Flooding at Combe: Report. Commissioned by Liverpool and Victoria Insurance. $13 \mathrm{p}$.

[50] Clark, C. (1983) Bruton Flood Alleviation Scheme: Benefit Assessment. Report to Wessex Water Authority. 21 p.

Submit or recommend next manuscript to SCIRP and we will provide best service for you:

Accepting pre-submission inquiries through Email, Facebook, LinkedIn, Twitter, etc. A wide selection of journals (inclusive of 9 subjects, more than 200 journals) Providing 24-hour high-quality service User-friendly online submission system Fair and swift peer-review system Efficient typesetting and proofreading procedure Display of the result of downloads and visits, as well as the number of cited articles Maximum dissemination of your research work

Submit your manuscript at: http://papersubmission.scirp.org/ Or contact gep@scirp.org 